\title{
Hematological Indices of the Lake Frog Pelophylax ridibundus (Pallas, 1771) (Ranidae, Anura) \\ Inhabiting Reservoirs in the Northwestern Ciscaucasia with Various Pollution Types
}

\author{
Tatyana Yu. Peskova, Olga N. Bachevskaya, and Gennady K. Plotnikov
}

\author{
Kuban State University \\ 149 Stavropolskaya Str., Krasnodar 350040, Russia \\ E-mail:peskova@kubannet.ru
}

Received 20 February 2018, revised 11 May 2018, accepted 26 July 2018

\begin{abstract}
The paper deals with hematological indices of lake frogs from two biotopes with different pollution types. The first biotope is the Chibi Canal, which receives water from rice bays, it is contaminated with pesticides. The second biotope is a reservoir near the old river-bed of the Kuban River near the forest park Krasny Kut. In both biotopes, no significant differences in the number of erythrocytes and hemoglobin in the blood of lake frogs were observed. Monocytosis, a leftward shift of the neutrophilic cell series, and eosinophilia were revealed in the leukocyte formula of the lake frog blood. These changes are adaptive. Thus, the water quality in the surveyed reservoirs is assumed to be good from April till September 2017, and the effluents falling into them had no pathological effect on lake frogs.

Key words: lake frog, hematological indices, reservoirs, pesticide pollution, sewage pollution.
\end{abstract}

DOI: https://doi.org/10.18500/1814-6090-2019-19-1-2-40-45

\section{INTRODUCTION}

Surveillance studies of the ecological status of the biotopes are conducted regularly. Analyses of the data obtained make it possible to assess the dynamics of the changes occurring in them. Lake frog (Pelophylax ridibundus (Pallas, 1771)) spend most of their life in water; therefore, they are convenient objects for the surveillance study of the state of various water reservoir types. The dynamics of the physiological state of lake frogs, in particular their hematological indices, promptly responds to water quality changes in the reservoir.

This work aims to assess the state of two natural biotopes with different types of pollution through determining the hematological indices of lake frogs during the spring and summer seasons of 2017.

\section{MATERIAL AND METHODS}

The sampling of amphibians was carried out in the two reservoirs from April till September 2017. The objects of the study were sexually mature lake frogs with body dimensions of $68 \sim 111 \mathrm{~mm}$. The study was conducted at the Chibi Canal and reservoirs of the Krasny Kut forest park. A total of 109 individuals were collected (in April - 9 and 8 ind., in May -8 and 10 ind., in June -10 and 9 ind., in July -10 and 10 ind., in August -9 and 8 ind., in September -8 and 10 ind. in the Chibi Canal and reservoirs of the Krasny Kut forest park respectively.
The Chibi Canal (Republic of Adygea, Takhtamukai district) flows $10 \mathrm{~km}$ away from the border of the City of Krasnodar. Its banks are shallow, overgrown with reeds, cattail, and mixed grass. The canal is surrounded by rice bays. In the place of the experimental sampling, two drainage pipes enter the reservoir, carrying water directly from the rice bays. Highway A146 (Krasnodar-Novorossiysk) is located at a distance of 10 15 meters from the bank line. On the bank, there is a sign that there is an oil pipeline in the adjoining area. The main pollutants are pesticides that enter the water from the rice bays.

The second examined reservoir is next to the old river bed of the Kuban River in the Krasny Kut forest park. It is located in the southern part of Krasnodar on the right bank of the Kuban River, $10 \mathrm{~km}$ away from the city center. The banks of the river are steep, bold, blocked by a concrete dam. There is a lock system and a pumping station. A boat station, a holiday village, and FSI SIZO-1 of the UFSIN of Russia in the Krasnodar Territory are located nearby. The vegetation cover is represented by woody plants, such as willow, Caspian willow, poplar, maple, and birch. The dominating annual plants are water nuts, reeds, and mixed herbs. The main pollution is sewage.

The main hydrochemical indices of pollution of water reservoirs are shown in Table 1. This analysis of water was made in the ecological and analytical center of the Kuban State University.

Hematological indices such as the number of erythrocytes, leukocytes, the leukocyte formula, the amount of hemoglobin, and the color index according to standard methods were included in the scope of the study (Hematology, 2004). 
Table 1. Main hydrochemical indices of pollution of water reservoirs

\begin{tabular}{l|c|c|c}
\hline \multicolumn{1}{c|}{ Index } & $\begin{array}{c}\text { Chibi } \\
\text { Canal }\end{array}$ & $\begin{array}{c}\text { Reservoirs } \\
\text { of the } \\
\text { Krasny Kut } \\
\text { forest park }\end{array}$ & MPC \\
\hline BOD & 17.2 & 22.6 & $3.0-6.0$ \\
\hline ChOD & 32.5 & 29.1 & absent \\
\hline Nitrogen of nitrite & 0.02 & 0.03 & 0.02 \\
\hline Nitrogen of nitrate & 0.08 & 0.14 & 9.1 \\
\hline Phosphates & 0.10 & 0.12 & 0.20 \\
\hline Chlorides & 152.3 & 120.40 & 350.0 \\
\hline Sulfates & 38.1 & 29.80 & 100.0 \\
\hline Pesticide aldrine & 0.01 & absent & 0.002 \\
\hline Oil products & 0.03 & 0.06 & 0.05
\end{tabular}

A statistical analysis of the obtained data was carried out by standard methods (Lakin, 1990). The reliability of the differences is determined at the $5 \%$ level of significance.

\section{RESULTS AND DISCUSSION}

The red blood indices of lake frogs from the two reservoirs are provided in Table 2.

The erythrocyte content in the blood of lake frogs from the studied biotopes did not differ significantly in all months. In both biotopes, the erythrocyte content decreases in April and August, and in the Chibi Canal also in September compared with other months. The reference values of the erythrocyte con-tent in tailless amphibians are 300 400 thousand/ $\mathrm{mm}^{3}$ (Motuzko et al., 2000). Accordingly, the values observed in April, August, and September fall outside the lower limit of the normal values of this index. Judging by theTable 3, the month of the study (air temperature) and the interaction of the reservoir - month significantly affect on the number of red blood cells.

Table 2. Main red blood indices of lake frogs inhabiting reservoirs with different types of contaminants $(X \pm m)$

\begin{tabular}{l|c|c|c|c}
\hline \multirow{4}{*}{ Reservoir } & $\begin{array}{c}\text { Month } \\
\text { of study }\end{array}$ & $\begin{array}{c}\text { Number of } \\
\text { erythrocytes } \\
\text { (in thousand/mm }\end{array}$ & $\begin{array}{c}\text { Amount of } \\
\text { hemoglobin }(\mathrm{g} / \mathrm{l})\end{array}$ & $\begin{array}{c}\text { Color } \\
\text { index }\end{array}$ \\
\hline \multirow{2}{*}{ Chibi Canal } & April & $256 \pm 28.7$ & $79.9 \pm 3.99$ & 1.04 \\
\cline { 2 - 5 } & May & $310 \pm 22.6$ & $98.8 \pm 4.14$ & 0.97 \\
\cline { 2 - 5 } & June & $355 \pm 39.1$ & $75.3 \pm 2.08$ & 0.66 \\
\cline { 2 - 5 } & July & $331 \pm 12.1$ & $72.7 \pm 1.52$ & 0.66 \\
\cline { 2 - 5 } & August & $234 \pm 22.2$ & $77.6 \pm 3.79$ & 1.08 \\
\cline { 2 - 5 } & September & $234 \pm 14.2$ & $95.7 \pm 5.11$ & 1.34 \\
\hline \multirow{2}{*}{$\begin{array}{l}\text { Keservoirs of the Kut fo- } \\
\text { rest park }\end{array}$} & April & $195 \pm 7.0$ & $90.7 \pm 2.44$ & 1.33 \\
\cline { 2 - 5 } & May & $365 \pm 30.9$ & $101.5 \pm 6.97$ & 0.88 \\
\cline { 2 - 5 } & June & $306 \pm 73.3$ & $80.9 \pm 3.85$ & 0.84 \\
\cline { 2 - 5 } & July & $321 \pm 10.2$ & $78.3 \pm 1.79$ & 0.74 \\
\cline { 2 - 5 } & August & $270 \pm 28.0$ & $79.4 \pm 4.07$ & 0.92 \\
\cline { 2 - 5 } & September & $321 \pm 9.4$ & $98.5 \pm 9.57$ & 0.93
\end{tabular}
rice bay, the average erythrocyte content was $450 \pm 61.9$ thousand $/ \mathrm{mm}^{3}$ (Zhukova, 1987), i.e. 1.2 1.9 times more than in frogs from the Chibi $\mathrm{Ca}-$ nal, which the outlet pipes of the rice bays enter. The erythrocyte content in frogs from the pond contaminated by pesticides was $340 \pm 10.9$ thousand $/ \mathrm{mm}^{3}$ in spring and $650 \pm 12.2$ thousand $/ \mathrm{mm}^{3}$ in summer (Peskova, 2001). The spring data are comparable to ours, whereas in summer the frogs from the Chibi Canal had almost half the number of erythrocytes.

The lake frogs dwelling in the sewage waters of sugar refineries (Vafis, Peskova, 2009) had 139 310 thousand $/ \mathrm{mm}^{3}$ of erythrocytes, which is comparable to the data on frogs from Krasny Kut's reservoirs, which organic domestic wastewater falls into.

The hemoglobin content was significantly higher in frogs from Krasny Kut compared with specimens from the Chibi Canal in April and July $(t=2.3$, and 2.38 at $t_{s t}=2.10$ ). The same trend (but within the statistical uncertainty limits) persisted in other months of the study. The reference values of the hemoglobin content in tailless amphibians are 65 85 g/l (Motuzko et al., 2000). We noted that frogs from the Chibi Canal had an excess of the upper limit of the normal values of hemoglobin in May and September, while frogs from Krasny Kut's reservoirs had the same in April, May, and September. Judging by the Table 3, only one factor - the type of reservoir - affects on the amount of hemoglobin.

Compared with the published data, the hemoglobin content in frogs from the rice bay exceeded that of frogs from the Chibi Canal (Zhukova, 1987). A comparison with the data of another publication (Peskova, Zhukova, 2005) shows that the hemoglobin content is similar in spring $(89.0 \pm 7.72 \mathrm{~g} / 1)$ and higher in the rice bay in summer $(142.2 \pm 8.23 \mathrm{~g} / \mathrm{l})$ compared with our data.

The reference values of the color index for tailless amphibians are within the range of $0.6 \sim 0.7$ (Motuzko et al., 2000). In the Chibi Canal in spring and late summer and in Krasny Kut during the entire study season, we observed hyperchromia in lake frogs. This is confirmed by a lower erythrocyte content in the blood of frogs from the Chibi Canal. Frogs from the reservoirs of Krasny Kut had a lower erythrocyte content only in April; during that month, they have the maximum value of the color index of blood.

The total leukocytes content in the blood of lake frogs from the two biotopes studied is shown in Figure. 
Tatyana Yu. Peskova, Olga N. Bachevskaya, and Gennady K. Plotnikov

Table 3. The results of two-factor analysis of variance variability of the main hematological parameters of lake frogs from two reservoirs in different seasons

\begin{tabular}{l|c|c|c|c|c}
\hline Source of variation & $\begin{array}{c}\text { SS } \\
\text { sum of } \\
\text { squares }\end{array}$ & $\begin{array}{c}\text { dF } \\
\text { number of } \\
\text { degrees of } \\
\text { freedom }\end{array}$ & $\begin{array}{c}\text { MS } \\
\text { mean } \\
\text { square }\end{array}$ & $\begin{array}{c}F \\
\text { Fisher' } \\
\text { criterion }\end{array}$ & $\begin{array}{c}p \\
\text { significance } \\
\text { level }\end{array}$ \\
\hline Month & 181889 & 4 & 45472 & 8.14 & 0.00 \\
\hline Reservoir & 3577 & 1 & 3577 & 0.64 & 0.43 \\
\hline Month - Reservoir & 75118 & 4 & 18780 & 3.36 & 0.01 \\
\hline Error & 446719 & 80 & 5584 & - & - \\
\hline \multicolumn{7}{|c|}{ Amount of hemoglobin } \\
\hline Month & 556.7 & 1 & 556.7 & 3.1 & 0.0808 \\
\hline Reservoir & 7617.5 & 4 & 1904.4 & 10.7 & 0.0000 \\
\hline Month - Reservoir & 297.3 & 4 & 74.3 & 0.4 & 0.7955 \\
\hline Error & 14238.6 & 80 & 178.0 & - & - \\
\hline \multicolumn{7}{|c|}{ Number of leukocytes } \\
\hline Month & 241.4 & 1 & 241.4 & 8.1 & 0.006 \\
\hline Reservoir & 403.2 & 4 & 100.8 & 3.4 & 0.013 \\
\hline Month - Reservoir & 181.8 & 4 & 45.4 & 1.5 & 0.201 \\
\hline Error & 2375.6 & 80 & 29.7 & - & -
\end{tabular}

the reservoir, but their interaction has no effect on the number of white blood cells.

Earlier, leukocytosis was observed in lake frogs from the rice bay (Zhukova, 1987): $52.3 \pm 4.54$ thousand $/ \mathrm{mm}^{3}$. In the Karasun Lake located within Krasnodar (Zhukova, Fits, 1996) and also containing pesticides in its water, the observed leukocyte content was comparable to our data (19.9 thousand $/ \mathrm{mm}^{3}$ ). Similar values were also observed in spring $(13.4 \pm 1.9$ thousand $/ \mathrm{mm}^{3}$ ) and in summer $\left(22.5 \pm 2.1\right.$ thousand $\left./ \mathrm{mm}^{3}\right)$ in frogs from another rice bay (Peskova, Zhukova, 2005).

The leukocyte formu-la of lake frogs from the investigated biotopes in different months of 2017 is provided in Table 4.

An analysis of the non-grained leukocyte con-

Judging from the data in Figure, the leukocyte content in the blood of amphibians inhabiting the Chibi Canal in spring and summer exceeds this index of amphibians from Krasny Kut by 1.2 2.6 times; however, a significant increase was noted only in May $\left(t=2.16\right.$ at $\left.t_{s t}=2.10\right)$ and July $\left(t=3.02\right.$ at $\left.t_{s t}=2.10\right)$. In this case, the reference leukocyte content values in tailless amphibians are 2 20 thousand $/ \mathrm{mm}^{3}$ (Motuzko et al., 2000). The number of leukocytes in the blood of frogs from both reservoirs testifies to the normal leukocyte content. This value exceeds the upper limit of the standard value for frogs from the Chibi Canal only in May. Judging by the Table 3, the number of leukocytes is influenced by 2 factors - the month and

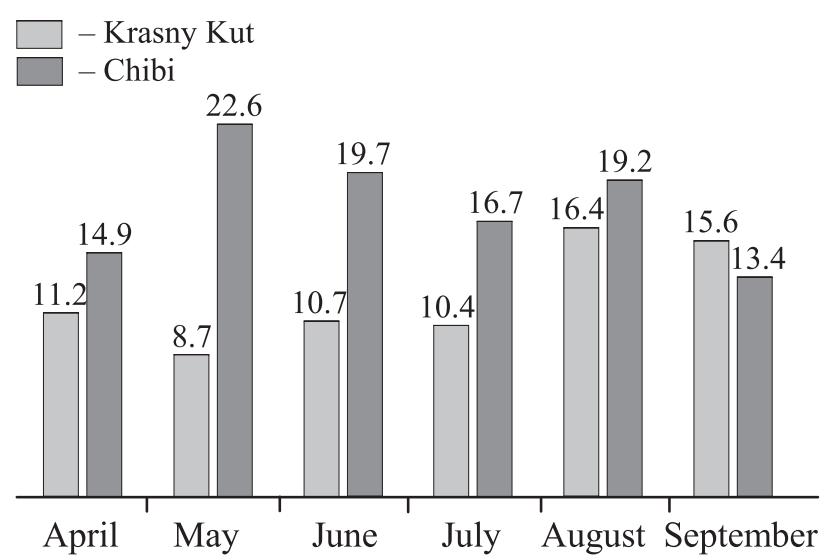

Figure. Leukocyte content (thousand $/ \mathrm{mm}^{3}$ ) in the blood of lake frogs from two biotopes with different types of pollutants tent showed that there were no significant differences in the number of lymphocytes and monocytes in the blood of frogs from the two reservoirs during all months of the study. A comparison of our data with reference values (40 60\% for lymphocytes, 1 3\% for monocytes) (Motuzko et al., 2000) indicates the presence of monocytosis in frogs from both reservoirs and the normal lymphocyte content.

The total number of lymphocytes is comparable to their number in the blood of frogs from the rice bays, outlet channels, sewage of sugar refineries (Zhukova, 1987; Peskova, Zhukova, 2005; Vafis, Peskova, 2009). The monocyte content is similar to that in frogs from the sewage of sugar refineries (Vafis, Peskova, 2009), but exceeds that of frogs from the outlet channels of the rice bays (Zhukova, 1987). Thus, the blood of frogs from the reservoirs of Krasny Kut and the Chibi Canal is lymphoid.

Lymphocytes play a significant role in the implementation of immunological response of the body. Monocytes, active phagocytes of blood, absorb the cell and tissue decay products. Their increased content in the blood indicates an increase in the defensive ability of the body (Zhiteneva et al., 2004).

Among granular leukocytes, neutrophils account for the largest number. A comparison of different groups of stab granular leukocyte content in the blood of lake frogs from the two reservoirs under study shows the presence of significant differences in the content of both stab $\left(t=2.33\right.$ at $\left.t_{s t}=2.10\right)$ and segmented $\left(t=3.30\right.$ at $\left.t_{s t}=2.10\right)$ neutrophils only in April 2017 . 
Hematological Indices of the Lake Frog

Table 4. Leukocyte formula of lake frogs inhabiting biotopes with different types of contaminants $(X \pm m)$

\begin{tabular}{|c|c|c|c|c|c|c|}
\hline \multirow{2}{*}{ Leukocyte type } & \multicolumn{6}{|c|}{ Month of study } \\
\hline & April & May & June & July & August & September \\
\hline \multicolumn{7}{|c|}{ Chibi Canal } \\
\hline Stab neutrophils & $9.5 \pm 1.37$ & $8.8 \pm 1.26$ & $5.6 \pm 1.16$ & $9.0 \pm 1.52$ & $5.1 \pm 1.17$ & $8.4 \pm 1.55$ \\
\hline Segmented neutrophils & $15.5 \pm 1.75$ & $12.7 \pm 1.69$ & $22.2 \pm 1.94$ & $17.3 \pm 1.56$ & $20.4 \pm 1.77$ & $16.5 \pm 1.90$ \\
\hline Eosinophils & $11.2 \pm 1.94$ & $6.1 \pm 1.28$ & $7.0 \pm 1.94$ & $10.7 \pm 2.30$ & $8.2 \pm 1.81$ & $9.8 \pm 1.80$ \\
\hline Basophils & $2.3 \pm 0.85$ & $1.0 \pm 0.12$ & $1.5 \pm 0.56$ & $1.0 \pm 0.37$ & 0.5 & $1.2 \pm 0.18$ \\
\hline Monocytes & $10.9 \pm 1.93$ & $8.7 \pm 0.71$ & $15.7 \pm 4.11$ & $10.5 \pm 0.85$ & $12.4 \pm 2.00$ & $18.1 \pm 3.60$ \\
\hline Lymphocytes & $52.6 \pm 3.49$ & $56.0 \pm 5.86$ & $47.9 \pm 4.82$ & $51.4 \pm 3.18$ & $53.40 \pm 3.23$ & $45.9 \pm 3.71$ \\
\hline \multicolumn{7}{|c|}{ Reservoirs of the Krasny Kut forest park } \\
\hline Stab neutrophils & $5.4 \pm 1.11$ & $8.1 \pm 1.83$ & $5.0 \pm 2.13$ & $9.7 \pm 1.30$ & $8.1 \pm 1.33$ & $12.1 \pm 2.60$ \\
\hline Segmented neutrophils & $23.0 \pm 1.45$ & $18.5 \pm 3.18$ & $22.3 \pm 2.94$ & $19.4 \pm 1.42$ & $19.4 \pm 2.65$ & $17.6 \pm 1.62$ \\
\hline Eosinophils & $5.2 \pm 0.59$ & $7.7 \pm 2.44$ & $6.8 \pm 2.73$ & $10.0 \pm 1.90$ & $15.3 \pm 2.79$ & $8.6 \pm 0.76$ \\
\hline Basophils & 0.81 & 0.38 & $1.8 \pm 1.14$ & 0.33 & $0.8 \pm 0.28$ & $1.6 \pm 0.21$ \\
\hline Monocytes & $9.2 \pm 0.99$ & $9.0 \pm 0.53$ & $10.7 \pm 4.98$ & $8.4 \pm 1.22$ & $14.3 \pm 1.85$ & $13.5 \pm 3.10$ \\
\hline Lymphocytes & $56.7 \pm 2.39$ & $56.1 \pm 5.72$ & $53.3 \pm 6.46$ & $51.7 \pm 2.59$ & $42.6 \pm 5.41$ & $46.6 \pm 3.43$ \\
\hline
\end{tabular}

A comparison with the reference content values of the stab (2 4\%) and segmented (20 30\%) neutrophils (Motuzko et al., 2000) showed a shift toward younger cells in frogs from both reservoirs. The shift of neutrophil nuclei to the left is the sign of a pathological process in the animal's body.

In an earlier study (Zhukova, 1987), a similar proportion of young and mature neutrophil forms was observed (9\% of stab cells, $25 \%$ of segmented cells) compared with our data on frogs from the Chibi Canal. The blood of lake frogs inhabiting sewage waters from sugar refineries (Vafis, Peskova, 2009) was characterized with general neutrophilia with an increase in the number of both young and mature cells. This phenomenon was not observed in the reservoirs of Krasny Kut, where domestic wastewater enters the reservoir.

Neutrophils have the most pronounced motor activity; they periodically go beyond the bloodstream and pass into tissues where they phagocyte microbes and cell decay products. The main function of neutrophils is the body protection from infections and toxic effects. Neutrophilia is considered to be an adaptive response of the body that occurs under the effect of various toxicants (Zhiteneva et al., 2004).

The basophil content in the blood of frogs from both biotopes under study did not differ significantly during the entire investigated season. The eosinophil content was significantly different in two months of the study $\left(t=2.96\right.$ and 2.14 at $\left.t_{s t}=2.10\right)$. It was greater in animals from the Chibi Canal in April and in animals from the reservoirs of Krasny Kut in August. Frogs from the rice bay had a similar basophil content (2\%), but a significantly larger number of eosinophils (22\%) (Zhukova, 1987). After a prolonged exposure to high concentrations of toxicants, the eosinophil content in frogs increased to $20 \sim 30 \%$, which characterizes pathological changes in the frogs' blood (Zhukova, Peskova, 1999).

The reference content values of basophils are within the range of $10 \sim 20 \%$ and eosinophils within 3 10\% (Motuzko et al., 2000). Judging by these data, basophilopenia and, occasionally, small eosinophilia were observed in the frogs from both reservoirs during the entire period of investigation.

Eosinophils are emergency response cells. They can adsorb protein-based toxicants, but do not have the ability to synthesize antibodies (Zhiteneva et al., 2004). Judging by their content in the blood of the experimental frogs, there is only chronic pollution in both reservoirs, which does not severely affect amphibians.

The function of basophils is to ensure the migration of leukocytes of other types into tissues; they actively participate in the development of allergic reactions of the anaphylactic shock type. Basophilopenia is a characteristic response in the development of stress in an animal (Zhiteneva et al., 2004).

T. Yu. Peskova (2001) identified two types of changes in the leukocyte formula of the lake frog: adaptive and pathological. The adaptive type of changes in white blood includes an increase in the number of young neutrophils and monocytes with varying changes in the lymphocyte and eosinophil content. The pathological type of changes in the white blood of amphibians includes neutropenia in combination with monocytosis and eosinophilia or lymphocytosis.

\section{CONCLUSION}

In both reservoirs, there were no significant differences in the content of erythrocytes and hemoglobin in the blood of lake frogs; however, hyper- 
chromia was detected. Monocytosis, a shift of the neutrophilic cell series to the left and, in some cases, eosinophilia were observed in the white blood of lake frogs; all of these changes are adaptive. Thus, we can state that the water quality in the studied reservoirs was good from April to September 2017; the effluents falling into them did not have a pathological effect on the life activity of tailless amphibians.

\section{REFERENCES}

Hematology: The Newest Directory. K. M. Abdulkabyrov, ed. Moscow, St. Petersburg, Eksmo Publ., 2004. 928 p. (in Russian).

Lakin G. F. Biometrics. Moscow, Nauka Publ., 1990. 352 p. (in Russian).

Motuzko N. S., Nikitin Yu. I., Martsenyuk A. P. Handbook of Clinical and Biological Indices of Animals. Vitebsk, 2000. 68 p (in Russian).

Peskova T. Yu. Impact of Anthropogenic Environment Pollution on Amphibians. Volgograd, Volgograd State Pedagogical University Publ., 2001. 156 p. (in Russian).

Peskova T. Yu., Zhukova T. I. Hematological Indexes of Rana ridibunda in Clean and Contaminated
Ponds. Herpetologia Petropolitana: Proceedings of the 12th Ordinary General Meeting of the Societas Europaea Herpetologica. St. Petersburg, 2005, pp. 296-297.

Vafis A. A., Peskova T. Yu. Blood Response of the Lake Frog Rana ridibunda Pal. to the Impact of Sewage of Sugar Refineries. Problems of Contemporary Science and Practice, 2009, no. 2, pp. 8-18 (in Russian).

Zhiteneva L. D., Makarov E. V., Rudnitskaya O. A. The fundamentals of ichthtyohematology (in comparative aspekts). Rostov-on-Don, Everest Publ., 2004. 311 p. (in Russian).

Zhukova T. I. Changes in Hematological Indices of the Lake Frog due to Habitation in Reservoirs Polluted with Pesticides. Russian J. of Ecology, 1987, no. 2, pp. 54-60 (in Russian).

Zhukova T. I., Peskova T. Yu. Blood Response of Tailless Amphibians to Pesticide Pollution. Russian J. of Ecology, 1999, no. 4, pp. 288-292 (in Russian).

Zhukova T. I., Fits I. V. Comparative Characteristic of Hematological Indices of the Lake Frog Inhabiting Reservoirs with Different Pollution Degree. In: Current Issues of Ecology and Conservation of Ecosystems in the Southern and Central Regions of Russia. Krasnodar, Kuban State University Publ., 1996, pp. 160-162 (in Russian).

\section{Cite this article as:}

Peskova T. Yu., Bachevskaya O. N., Plotnikov G. K. Hematological Indices of the Lake Frog Pelophylax ridibundus (Pallas, 1771) (Ranidae, Anura) Inhabiting Reservoirs in the Northwestern Ciscaucasia with Various Pollution Types. Current Studies in Herpetology, 2019, vol. 19, iss. 1-2, pp. 40-45 (in Russian). DOI: https://doi.org/10.18500/1814-60902019-19-1-2-40-45 
Hematological Indices of the Lake Frog

УдК [597.851:576.89](470.620)

\section{Гематологические показатели озёрной лягушки \\ Pelophylax ridibundus (Pallas, 1771) (Ranidae, Anura) \\ из водоёмов Северо-Западного Предкавказья с различными типами загрязнения}

\section{Т. Ю. Пескова, О. Н. Бачевская, Г. К. Плотников}

Кубанский государственньий университет

Россия, 350040, Краснодар, Ставропольская, 149

E-mail:peskova@kubannet.ru

Поступила в редакцию 20.02.2018, после доработки 11.05.2018, принята 26.07.2018

В статье рассмотрены гематологические показатели озёрной лягушки из двух биотопов с разными типами загрязнения. Первый биотоп - Чибийский магистральный канал, куда попадает вода с рисовых чеков, он загрязнен пестицидами. Второй биотоп - водоём рядом со старым руслом р. Кубань возле лесопарка Красный Кут. В обоих биотопах не отмечено достоверных отличий по количеству эритроцитов и гемоглобина в крови озёрных лягушек. В лейкоцитарной формуле крови озёрных лягушек отмечены моноцитоз, сдвиг нейтрофильного ряда клеток влево и эозинофилия. Эти изменения являются адаптивными. Таким образом, можно говорить о том, что качество воды в исследованных водоёмах с апреля по сентябрь 2017 г. было хорошим и попадающие в них стоки не оказывают патологического влияния на озёрных лягушек.

Ключевые слова: озёрная лягушка, гематологические показатели, водоёмы, пестицидное загрязнение, бытовое загрязнение.

DOI: https://doi.org/10.18500/1814-6090-2019-19-1-2-40-45

\section{Образец для цитирования:}

Peskova T. Yu., Bachevskaya O. N., Plotnikov G. K. 2019. Hematological Indices of the Lake Frog Pelophylax ridibundus (Pallas, 1771) (Ranidae, Anura) Inhabiting Reservoirs in the Northwestern Ciscaucasia with Various Pollution Types [Пескова T. Ю., Бачевская О. Н., Плотников Г. К. 2019. Гематологические показатели озёрной лягушки Pelophylax ridibundus (Pallas, 1771) (Ranidae, Anura) из водоёмов Северо-Западного Предкавказья с различными типами загрязнения] // Современная герпетология. Т. 19, вып. 1/2. C. $40-45$. DOI: https://doi.org/10.18500/1814-6090-2019-19-1-2-40-45 